\title{
Social Network Analysis of Stakeholder on a Conflict Accomplishment of Regional Border Areas in Magelang City
}

\author{
Eny Boedi Orbawati ${ }^{1}$, Sri Suwitri ${ }^{2}$, Sri Mulyani $^{3}$, Atika Indah N Atsarina ${ }^{4}$ \\ \{ enybudiorbawati@gmail.com ${ }^{1}$, witkusdali@gmail.com ${ }^{2}$, hartomomulyani@gmail.com ${ }^{3}$, \\ atikaatsarina@gmail.com ${ }^{4}$ \} \\ Tidar University ${ }^{1,2,3}$, Gadjah Mada University $^{4}$
}

\begin{abstract}
Territorial boundaries take an important role in the implementation of government because its impact greatly affects the various policies that accompany it. There is a conflict in the affirmation of the regional boundary between Magelang City and Magelang Regency that has not been resolved until now. Optimization measures can be taken if stakeholders and their role in the affirmation of territorial boundaries can be properly identified. The method used in this study is Social Network Analysis (SNA). It aims to examine the pattern of relationship between stakeholders in the affirmation of regional boundaries. Data processing using open source UCINET software. SNA method successfully describes the pattern of interaction between stakeholders in affirming the boundaries between Magelang City and Magelang Regency and the level of contribution.
\end{abstract}

Keywords: Regional boundary, stakeholder, social network analysis

\section{Introduction}

Decentralization has become a word associated with Public Sector Reform in developing countries and transition in the field of development [1]. The objectives and of decentralization policy according to [2] include as follows: 1) efficiency and effectiveness of providing services to the community, 2) increasing economic growth and development, 3 ) increasing community participation in politics and development, 4) increasing effectiveness of coordination and development supervision.

In the regional autonomy era, aspects of the region become very important because the local authority covers the region's territory. The phenomenon that occurs in the area that is doing the expansion of districts, cities and provinces in its implementation has difficulty arranging territorial boundaries. The region boundary has important and strategic significance and as one of the supporting capabilities of the implementation of regional autonomy, because the region is a regional boundary in exploring the potential of natural resources, taxes and regional levies. However, after the implementation of regional autonomy the determination of territorial boundaries still makes the problem among them is the boundary of the area between Magelang City and Magelang District?

Affirmation of territorial boundaries is necessary in the implementation of local government and regional autonomy as it relates to local authority and accompanying policies. Regional autonomy has a close relationship with decentralization, which is the embodiment of 
the delegation of authority and responsibility from the Central Government to the Local Government. Decentralization is defined as the transfer of planning and decision-making authority from the central government to central organizations in the region, local administrative units, semi-autonomous and parasternal organizations (companies), local governments or nongovernmental organizations [3].

The affirmation of Magelang City limits to date still has no agreement with Magelang Regency and also Military Academy abbreviated as AKMIL, thus causing an affirmation conflict of the regional boundary that lasted a long time since 1990 and until now has not been able to be resolved. The conflict intensified when it entered the regional autonomy era in 2001, namely the claim to the territorial boundaries in each District and Magelang City.

[4] in an article explaining the conflict is a process in which one party considers that selfinterest is influenced by the actions of the other party. The way the team handles conflicts significantly affects its performance. Conflicts are more likely to arise and escalate when cultural differences are present between the parties. [5] noted that literature examining why conflicts arise generally points to "differences or mismatching of stakeholders in interests, values, powers, perceptions and objectives" [5]. Different approaches to managing conflicts in a group environment can affect how teams coordinate and in temporary organizations, team coordination affects team efficiency along with overall project performance [4].

Thomas-Kilmann's conflict model explains that in an ideal world, a collaborative approach can be brought to conflict resolution. In fact, limited resources, time constraints, opposing values and disharmony goals often make a collaborative approach to conflict resolution inappropriate and unrealistic. Whether a collaborative approach is possible or not, understanding the motives, fears, and politics that drive conflict helps one better navigate conflict[6].

This paper observes at how the activities of the actors involved in resolving the conflict affirmation of the territorial boundaries between Magelang District and Magelang City as well as relationship between actors. This article focuses on the behavior between actors in efforts to resolve conflict affirmation of the territorial boundary between Magelang District and Magelang City. This paper uses communication network perspectives to see how actors establish communication and whom they communicate with in an effort to resolve boundary affirmation conflicts.

\subsection{Social Network and Social Network Analysis (SNA)}

Stakeholder partnerships are needed to discuss and negotiate public policy in broadly defined problem areas [7]. The social network analysis model can demonstrate the great potential to exam the behavior and interaction of various stakeholders [8]. SNA can be an efficient tool for assessing communication behavior in stakeholder management[9].SNA can make an important contribution, as interaction and dialogue between stakeholders is critical to improving decision-making and awareness on several topics [10]-[12] in [13].

SNA (Social Network Analysis) is a specific application of graph theory in which individuals and other social actors, such as groups, organizations, and so on, are depicted by knots and their social relationships are illustrated by lines, this mathematical model inaugurates the early insights that Moreno described[14], The SAGE Handbook of Social Network Analysis, 2011). [15] described social network analysis as an approach that focuses its attention on how relationships between stakeholders form a framework or structure that can be studied and analyzed by itself [16]. Social network analysis was a research technique that focuses on identifying and comparing relationships within and among individuals, groups, and systems to model interactions in the real world [13]. 
Components in the social network include as follows: 1) Nodes, can be a set of people, objects, events or so-called actors depicted by a drop. 2) Tie, i.e. the link between 1 point and another point in the network depicted with a line; 3) the current, in the diagram illustrated with arrows, signifies something flowing from one point to another through a bond that connects each point in the network [17].SNA approach developed to identify the most important actors in graphs with the centralityconcept [18].

\section{Methodology}

The research methods in this article are statistical-descriptive analysis and social network analysis. Statistical-descriptive analysis is data obtained from the processing of survey results in the form of statistics that explain the characteristics of the data then reviewed descriptively to explain the information contained in the data used in the research. Social network analysis is a model of inter-actor networking formed based on statistical-descriptive analysis results. The relationship between actors will illustrate the model of interaction built into the social network and know the actors who have important roles in the network.

SNA method is used to view the role of actors in the network. In its application, it is done by various ways such as; Change the survey result socio-gram into the UCINET dataset format (.\#\#d and .\#\#h) for the NetDraw software. Then apply the concept of degree and closeness centrality using the following equations[19]:

\section{Degree Centrality}

The concept of centrality with regard to the concept of sociometry in identifying individuals who act as 'stars' i.e. individuals who occupy central positions and become the center of attention [14]. Degree centrality calculation can be denoted in the following formula:

$$
C d=\sum \frac{d 1}{N-1}
$$

Where $\mathrm{Cd}$ is degree centrality, $\mathrm{d}$ is the number of ties (links) from actor to actor, and $\mathrm{N}$ is the number of population members.

2. Closeness centrality

Degree centrality illustrates how close actors (nodes) are to all the other actors in the network [19]. The proximity here is measured by how many steps an actor can contact or be contacted by other actors online. The formula calculates the closeness of centrality as follows:

$$
C c=\frac{N-1}{\sum D}
$$

Where, $\mathrm{Cc}$ is closeness centrality, $\mathrm{d}$ is the shortest path to other actors, and $\mathrm{N}$ is the number of population members. The closeness of centrality is 0 to 1 , which is the greater the number that shows the average distance of the actor with all the actors in the network.

The stages in this study are divided into five stages, namely the preparation stage with literature study, the stage of data collection using survey methods using questionnaires against several stakeholders, the stage of data processing by calculating the degree centrality and closeness centrality values of each actor. Then the calculation results are processed and analysis 
using Ucinet software. The next stage is the data analysis stage that will be done statisticaldescriptive analysis. The final stage is drafting the report.

\section{Finding and Discussion}

Sociogram is a graph that illustrates the pattern of relationships between actors in a network. The pattern of relationships and interactions between actors in the resolution of conflict affirmation of the regional boundary between Magelang District and Magelang City as a whole in this study shown in figure 1. The red circle on the seismogram shows actors who are active in the social network penetiation of the conflict affirmation of the regional boundary between the Regency and Magelang City. The sosiogram shown consists of 17 actors who are on the social network as a whole and visualized using NetDraw. The visualization of the network seismogram aims to illustrate the connectedness between actors in the social networkBased on figure 1 there are two actors who are active in social network interaction severing the affirmation conflict of the regional boundary between Magelang District and Magelang City, namely the Secretary of Magelang City and the Magelang City Government Department. Two elements are observed on the social network structure, including degree centrality and closeness centrality. These two elements can be used to analyze actors who have a role in the resolution of the conflict affirming the regional boundary between Magelang District and Magelang City.

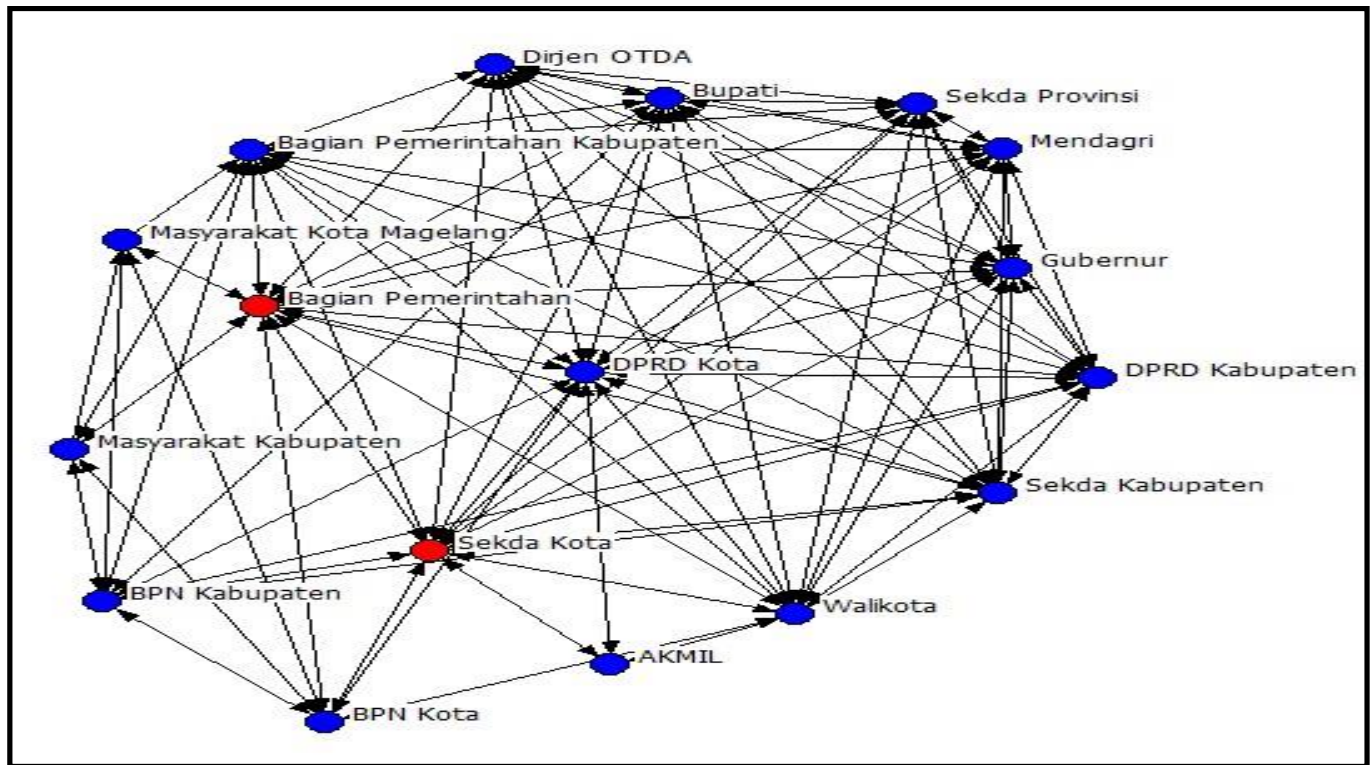

Notes:

Fig. 1. Sociogram all sample data

$$
\begin{aligned}
& =\text { Institution as highest degree centrality } \\
& =\text { Other institution }
\end{aligned}
$$




\subsection{Degree Centrality}

This degree shows the popularity of actors to influence and be influenced in social networks.

Table 1.

\begin{tabular}{lcc}
\hline & \multicolumn{2}{c}{ Value } \\
\cline { 2 - 3 } Institution & Out -Degree Centrality & In-Degree Centrality \\
\hline Government Level & 14,000 & 14,000 \\
Regional Secretary of City & 14,000 & 14,000 \\
Regional Representatives of City & 14,000 & 14,000 \\
District Government Level & 13,000 & 13,000 \\
Mayor & 13,000 & 14,000 \\
\hline
\end{tabular}

Degree centrality describes the relationship from one actor to another on the social network. Actors who are able to create more relationships with other actors are referred to as actors who have central roles. In this study, degree centrality is defined as an actor who has a great influence on the interactions formed in social networks.

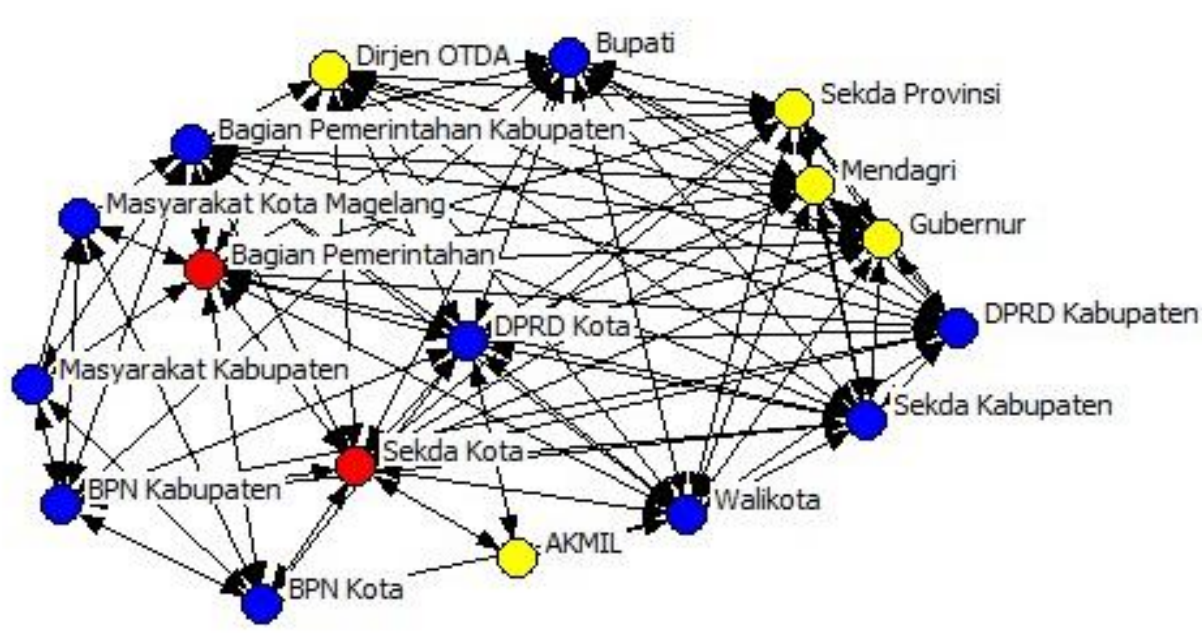

Fig. 2. Degree centrality sociogram all sample data 
Notes:

$=$ Institution as highest degree centrality

$=$ Regional Institution

$=$ Central/Provincial Institution

Table 2. Descriptive statistical of degree centrality

\begin{tabular}{|c|c|c|}
\hline \multirow[b]{2}{*}{ Measures } & \multicolumn{2}{|c|}{ Value } \\
\hline & Out-Degree Centrality & In-Degree Centrality \\
\hline Mean & 10,353 & 10,353 \\
\hline Standard Deviation & 3,429 & 3,580 \\
\hline Min & 3,000 & 3,000 \\
\hline Max & 14,000 & 14,000 \\
\hline & \multicolumn{2}{|c|}{ Network Degree Centrality Index } \\
\hline Out-Degree & \multicolumn{2}{|c|}{$24,219 \%$} \\
\hline In-Degree & \multicolumn{2}{|c|}{$24,219 \%$} \\
\hline
\end{tabular}

The ability of actors to influence the social network in the completion of the conflict affirmation of the regional boundary between the Regency and Magelang City can be seen with the value of the network degree centrality index. The value of the network out-degree centrality index illustrates that actors have roles and influences in social networks because they can exchange information. While the value of this network-degree centrality index illustrates that important actors try to connect in social networks. Based on table 2, the network out-degree centrality index is $24.219 \%$ and the value of the network in-degree centrality index is equal to $24.219 \%$. Network centrality as a whole is low, below 50\%. This suggests that the influence of actors does not vary in social networks.

\subsection{Closeness Centrality}

The centrality of proximity illustrates how close the actor (node) is to all the other actors in the network. Proximity is measured by how many steps an actor can contact or be contacted by another actor online. 
Table 3.

\begin{tabular}{lcc}
\hline & \multicolumn{2}{c}{ Value } \\
\cline { 2 - 3 } Institution & Out -Closeness Centrality & In-Closeness Centrality \\
\hline Government Level & 88,889 & 88,889 \\
Regional Secretary of City & 88,889 & 88,889 \\
Regional Representatives of City & 88,889 & 88,889 \\
Mayor & 84,211 & 88,889 \\
District Government Level & 84,211 & 84,211 \\
\hline
\end{tabular}

Table 4. Statistical Descriptive of closeness centrality

\begin{tabular}{lcc}
\hline & \multicolumn{2}{c}{ Value } \\
\cline { 2 - 3 } Measures & Out -Closeness Centrality & In-Closeness Centrality \\
\hline Standard Deviation & 11,474 & 11,930 \\
Min & 51,613 & 51,613 \\
Max & 88,889 & 88,889 \\
\hline
\end{tabular}

Network Closeness Centrality Index

$\begin{array}{ll}\text { Out-Closeness } & 30,20 \% \\ \text { In-Closeness } & 29,85 \%\end{array}$

The ability of actors to communicate in the resolution of conflict affirmation of the regional boundary between the Regency and Magelang City can be known by looking at the network closeness centrality index. The value of the network's out-closeness centrality index describes actors as having the proportions to influence other actors in conflict resolution on the social network. Meanwhile, network in-closeness centrality illustrates that actors have ease in establishing communication with other actors. The network out-closeness centrality index is $51.613 \%$ and the network in-closeness centrality index is $51.613 \%$. The out-closeness and incloseness values are equally high above $50 \%$ illustrating that actors tend to be easier to access the communication network. 


\section{Conclusion}

From the above discussion, it can be concluded that the intensity of interaction between actors is quite high can be seen from the density that is more than $50 \%$, by judging the value of the degree centrality and closeness centrality that serves as the central network, manufacturer, facilitator, and consumer of information in the network dominated by actors of Magelang City Government Section and The Secretary of Magelang City.

\section{References}

[1] C. J. Rees and F. Hossain, "Perspectives on decentralization and local governance in developing and transitional countries," Int. J. Public Adm., vol. 33, no. 12, pp. 581-587, 2010, doi: 10.1080/01900692.2010.514459.

[2] D. Lybecker and S. P. Mumme, "Decentralization and environmental protection on Mexico's northern and southern boundaries," J. Environ. Dev., 2002, doi: $10.1177 / 1070496502238664$.

[3] S. G. Cheema and D. a. Rondinelli, "From government decentralization to decentralized governance," Decentralizing Governance. Emerg. Concepts Pract., 2007.

[4] A. A. Tabassi, A. Abdullah, and D. J. Bryde, "Conflict Management, Team Coordination, and Performance Within Multicultural Temporary Projects: Evidence From the Construction Industry," Proj. Manag. J., vol. 50, no. 1, pp. 101-114, 2018, doi: $10.1177 / 8756972818818257$.

[5] C. Mc Dougall and M. Ram Banjade, "Social capital, conflict, and adaptive collaborative governance: Exploring the dialectic," Ecol. Soc., vol. 20, no. 1, 2015, doi: 10.5751/ES-07071-200144.

[6] C. A. Blair and D. E. Desplaces, "Conflict management through the negotiations canvas, getting participants to understand," Confl. Resolut. Q., vol. 36, no. 1, pp. 39-51, 2018, doi: $10.1002 /$ crq. 21227 .

[7] W. D. Leach, N. W. Pelkey, and P. A. Sabatier, "Stakeholder Partnerships as Collaborative Policymaking: Evaluation Criteria Applied to Watershed Management in California and Washington," Journal of Policy Analysis and Management, vol. 21, no. 4. pp. 645-670, 2002, doi: 10.1002/pam.10079.

[8] W. Xu, C. Zhou, A. Cao, and M. Luo, "Understanding the mechanism of food waste management by using stakeholder analysis and social network model: An industrial ecology perspective," Ecol. Modell., vol. 337, pp. 63-72, 2016, doi: 10.1016/j.ecolmodel.2016.06.006.

[9] G. Hosseininia, P. R. Khachak, M. Nooripoor, S. Van Passel, and H. Azadi, "Understanding communicational behavior among rangelands' stakeholders: application of social network analysis," Journal of Environmental Planning and Management, vol. 59, no. 2. pp. 320-341, 2015, doi: 10.1080/09640568.2015.1009975.

[10] K. André, L. Simonsson, Å. G. Swartling, and B. O. Linnér, "Method Development for Identifying and Analysing Stakeholders in Climate Change Adaptation Processes," J. Environ. Policy Plan., 2012, doi: 10.1080/1523908X.2012.702562.

[11] M. Evers et al., "Collaborative modelling for active involvement of stakeholders in urban flood risk management," Nat. Hazards Earth Syst. Sci., 2012, doi: 10.5194/nhess12-2821-2012. 
[12] T. S. Johansen and A. E. Nielsen, "Constructing Non-profit Identity in the Midst of Stakeholder Complexity," Int. Stud. Manag. Organ., 2016, doi: 10.1080/00208825.2016.1140518.

[13] M. Caniato, M. Vaccari, C. Visvanathan, and C. Zurbrügg, "Using social network and stakeholder analysis to help evaluate infectious waste management: A step towards a holistic assessment," Waste Manag., vol. 34, no. 5, pp. 938-951, 2014, doi: 10.1016/j.wasman.2014.02.011.

[14] J. Scott, "Social Network Analysis A Handbook." SAGE Publications Ltd, London, 2000.

[15] C. Eden, K. Page, and F. Ackermann, "Leading strategy making: Facilitating commitment to strategy," 2011, doi: 10.5464/AMBPP.2011.45.a.

[16] L. S. dos Muchangos, A. Tokai, and A. Hanashima, "Stakeholder analysis and social network analysis to evaluate the stakeholders of a MSWM system - A pilot study of Maputo City," Environ. Dev., vol. 24, no. October 2016, pp. 124-135, 2017, doi: 10.1016/j.envdev.2017.04.005.

[17] R. Agusyanto, Jaringan Sosial dalam Organisasi. Jakarta: Raja Grafindo Persada, 2014.

[18] Y. M. Manik, H. Sutanta, and D. Diyono, "Analyzing Stakeholders and Their Roles in Geospatial Information Utilization in local Government using Social Network Analysis Method," Semin. Nas. Geomatika 2017 Inov. Teknol. Penyedia Inf. Geospasial untuk Pembang. Berkelanjutan, no. February, 2018.

[19] Eriyanto, Analisis Jaringan Komunikasi. Jakarta: PRENADAMEDIA GROUP, 2014. 